OPEN ACCESS

Edited by:

Janine Barbara Adams, Nelson Mandela University,

South Africa

Reviewed by:

Teresa Fidelis,

University of Aveiro, Portugal

Nasreen Peer,

Stellenbosch University, South Africa

*Correspondence:

Pedro Coelho

pedrocoelho_pc2@hotmail.com

Specialty section This article was submitted to Marine Ecosystem Ecology,

a section of the journal

Frontiers in Marine Science

Received: 24 March 2021 Accepted: 05 July 2021

Published: 29 July 2021

Citation:

Coelho P, Carvalho F,

Goulding TA, Chainho P and

Guerreiro J (2021) Management

Models of the Manila Clam (Ruditapes philippinarum) Fisheries in Invaded

European Coastal Systems.

Front. Mar. Sci. 8:685307.

doi: 10.3389/fmars.2021.685307

\section{Management Models of the Manila Clam (Ruditapes philippinarum) Fisheries in Invaded European Coastal Systems}

\author{
Pedro Coelho' ${ }^{1 *}$, Frederico Carvalho', Thomas Goulding ${ }^{1}$, Paula Chainho ${ }^{1,2,3}$ and \\ José Guerreiro ${ }^{1,2}$ \\ ${ }^{1}$ Center for Marine and Environmental Sciences (MARE), Lisbon, Portugal, ${ }^{2}$ Department of Animal Biology, Faculty \\ of Sciences, University of Lisbon, Lisbon, Portugal, ${ }^{3}$ Instituto Politecnico de Setubal, Estefanilha, Portugal
}

The Manila clam (Ruditapes philippinarum, Adam \& Reeve 1850) is a non-indigenous species that was introduced in Europe (France) in the 1970s for commercial purposes, and reached Portugal in the 1980s. Currently, it occurs in several European coastal systems, from the Bay of Biscay to the north Mediterranean. In Portugal, it is present in estuarine systems and coastal lagoons from the north to south, such as Ria de Aveiro, Óbidos Lagoon and Sado estuary, but a sharp rise in the prevalence of this species in the largest Portuguese estuary, the Tagus, resulted in the exponential growth of the number of harvesters and, consequently, an increase in the illegal exploitation of this resource. At least 1700 harvesters were estimated in this system and an annual catch volume of between around 4,000 and 17,000 t which corresponds to an annual value around $€ 10,000,000$ to $€ 23,000,000$ of sales. There is a general failure to comply with current legislation, both in relation to harvesting and marketing, as well as constraints arising from spatial planning instruments in force on the estuary. The failure to comply with sanitary standards for the exploitation and trade of bivalve mollusks presents a risk to public health and a social-economic issue resulting from this activity. The goal of this study is to propose management models for this activity with the aim of contributing to create a legal framework in which sustainable harvesting can be achieved, in the different systems where exploitation occurs. In order to accomplish this goal, the current state play, legal framework, regulation for harvesting and trade and relevant spatial planning instruments in Portugal are analyzed. In order to ascertain an adequate national management strategy, a variety of case studies in France, Spain and Italy were studied. The outcome is a management model which includes a co-management strategy of concessions as well as a mixed regime with concession areas and free areas. The creation of specific regulations; implementation of a co-management model with the active participation of harvesters; science-based regulation of a closed season and maximum daily quotas and an improved surveillance of the activity are recommended.

Keywords: bivalve exploitation, Tagus estuary, legal framework, spatial planning instruments, management model 


\section{INTRODUCTION}

The management of coastal areas and the exploitation of their renewable resources leads to the integration of biological, economic and social sciences and is recognized worldwide as an important and relevant issue (Pastres et al., 2001; Bald et al., 2009). The production and exploitation of the Manila clam (Ruditapes philippinarum, Adams \& Reeve, 1850) has gained increasing importance worldwide in recent decades. This species is native to the Indo-Pacific area (Food and Agriculture Organization, 2020) and is characterized by high growth rates and an elevated tolerance to a wide range of environmental conditions European Union Regulation 1143/2014, sets rules to prevent and manage the introduction and spread of invasive alien species. However, Ruditapes philippinarum is included on a list found in Regulation 708/2007 which excludes it from the requirements outlined in Regulation 1143/2014, concerning the use of alien and locally absent species in aquaculture. Therefore, this species has no longer been considered as an invasive species but managed as a natural resource, requiring a group of measures that ensure sustainable exploitation, such as the definition of catch limitations based on estimates of fishing yields and the implementation of gear selectivity measures to ensure minimum landing sizes (Gorman et al., 2011).

Manila clam populations are usually highly abundant, easy to capture and purify and have strong market demand (Bidegain and Juanes, 2013). It became the preferred species for the clam production industry, which successfully boosted its introduction across the globe (Melià et al., 2004; Melià and Gatto, 2005; Bald et al., 2009). In Europe, overfishing and irregular yields of native clam species, like Ruditapes decussatus, resulted in the import of the Manila clam, which was first introduced in France (Bodoy et al., 1981) and its current European distribution ranges from the south coast of the British Isles to the northern Mediterranean (Garaulet, 2011). The species was also introduced in Ria Formosa, Portugal in the 1980s, and is currently distributed in several Portuguese coastal systems, including the Ria de Aveiro, Mondego estuary, Óbidos lagoon, Tagus and Sado estuaries and the Albufeira lagoon (Figure 1; Ruano and Sobral, 2000; Gaspar, 2010; Velez et al., 2015; Chiesa et al., 2016).

The current state of the Manila clam fishery in Portugal as well as the legal framework and spatial planning instruments in force in the studied systems are portrayed in this study, as a baseline for the development and future implementation of a management model. A cross comparison of the Portuguese and other European coastal systems where different fisheries models were implemented is used to select the best approaches for each case study.

In the Tagus estuary, recent studies show that the Manila clam is well distributed, usually in areas of lower depth and low concentrations of dissolved oxygen (Carvalho, 2017). Compared to other species with commercial interest, it is the most abundant and has a wider distribution area, mainly in the middle area of the estuary and shallow bays (Carvalho, 2017).

The species is also abundant, but not dominant, in the Sado estuary and in the Ria de Aveiro, where its occurrence was first reported in 2009 and 2011 (Chainho, 2014; Maia and Gaspar, 2014). Since its introduction in these systems, there has been a rapid spatial dispersion, evidencing its preference for habitats in shallower areas (Maia and Gaspar, 2014).

In the Obidos lagoon, a recent study revealed that, although it is already well established, it is still less abundant than the native species $R$. decussatus and presented a similar reproductive cycle (Duarte, 2018). Although $R$. decussatus is more abundant than the introduced species in this coastal lagoon, the co-occurrence of both species might represent a threat to the valuation of the native species due to the possibility of hybridization among the species, as was previously observed in the Ria de Vigo, Spain (Hurtado et al., 2011) and Ria de Aveiro, Portugal (Chiesa et al., 2014).

There is no comprehensive management model for the Manila clam in Portugal, although legislation has been tailored to areas where harvesting pressure is higher (Carvalho, 2017). Currently there are serious challenges in managing the harvesting activities and sale of this species due to several factors, such as shortfall in the issuing of licenses, use of illegal gear, absence of designated transposition zones, and a lack of specific regulations for the Sado estuary, Ria de Aveiro and Óbidos lagoon, where the species is commercially exploited. This activity is recognized as having a high socio-economic importance, requiring the analysis of possible governance scenarios for the creation of a fisheries management model of marine bivalve mollusks. Governance scenarios are understood as alternative ways of managing an activity, resource or area, regarding the current state, and providing information for the elaboration of a different management approach (Kuzdas and Wiek, 2014).

The main objective of this study is to identify a possible management model for the sustainable exploitation of the Manila clam in Portugal. using four different coastal systems where this species is harvested as case studies. This model is based on the integration of information related to:

- The current state of the Manila clam exploitation in each of the studied system;

- The compatibility or adaptability of the legal framework and spatial planning instruments with the current exploitation practices;

- The adequacy of management models used in other European coastal systems for each Portuguese case study.

\section{METHODOLOGY}

This study addresses four Portuguese coastal systems with different characteristics and in which the introduction of the Manila clam resulted in different impacts on the exploitation of its living resources (Figure 1):

(A) Ria de Aveiro - a large coastal lagoon where the species is abundant but not dominant and the exploitation occurs at the same level as other bivalve species (Maia and Gaspar, 2014);

(B) Óbidos lagoon - a small coastal lagoon where the species is also abundant but not dominant and with a smaller 


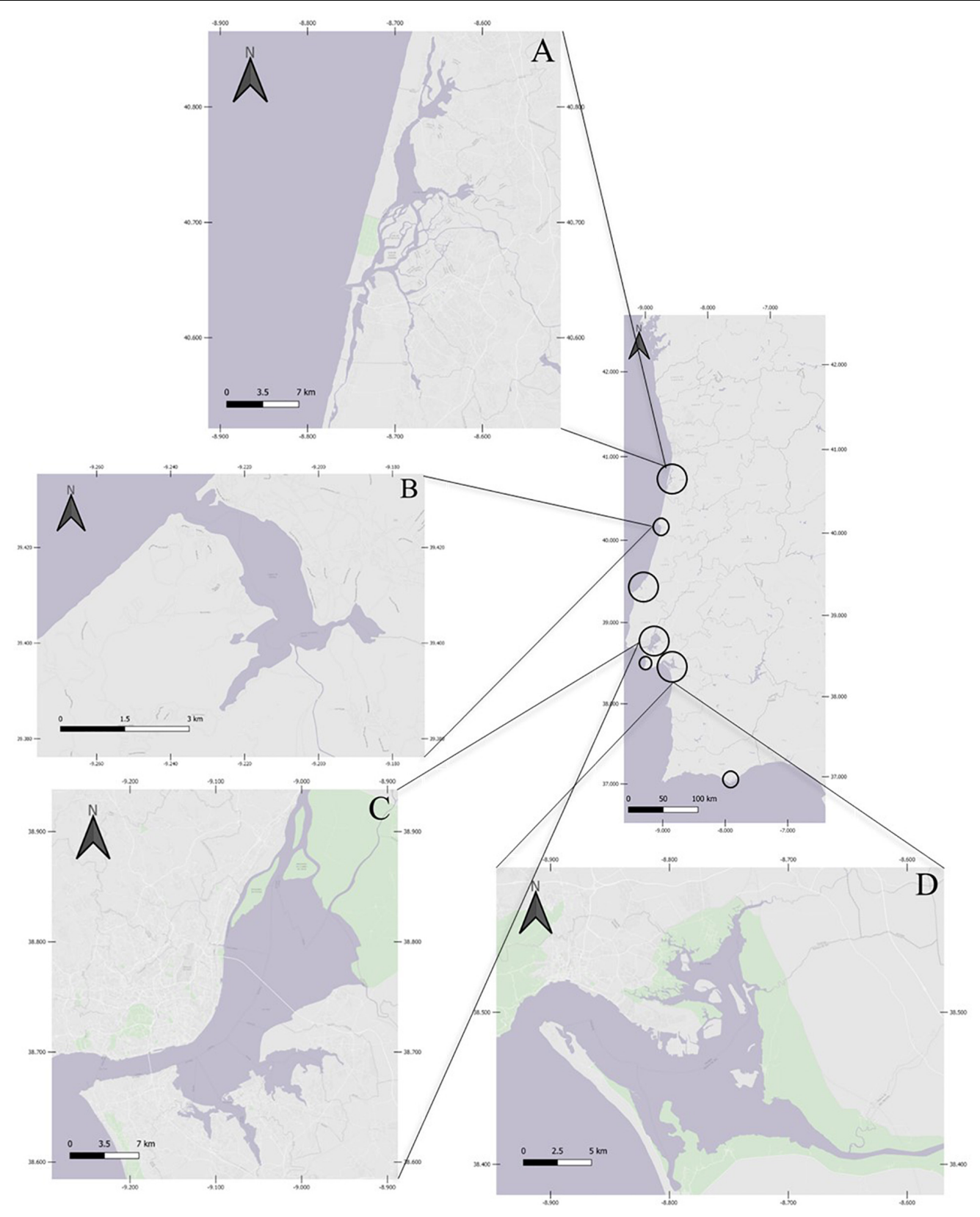

FIGURE 1 | Locations of estuaries and coastal lagoons where the Manila clam (Ruditapes philippinarum) has been recorded. From north to south of Portugal: Ria de Aveiro (A), Mondego Estuary, Óbidos Lagoon (B), Tagus Estuary (C), Albufeira Lagoon, Sado Estuary (D) and Ria Formosa. The letters mark the systems addressed in this manuscript.

fishing community compared with the other systems (Duarte, 2018);

(C) Tagus Estuary - the largest estuarine system in Portugal where the species is abundant and dominant and its exploitation is intensive with a large fishing community, that resort to illegal harvesting techniques (Ramajal et al., 2016; Carvalho, 2017);

(D) Sado Estuary - a large estuarine system where the species is also abundant but not dominant and its exploitation does not show much expression (Cabral et al., 2020).
In order to further explore the possible governance scenarios for the management of this resource we followed a four-step approach:

(i) Step 1 - Portrait of the Portuguese legal framework, based on a search conducted in the homepages of the Directorate General for Marine Resources (DGRM), the Portuguese Institute for Sea and Atmosphere (IPMA) and the Official Portuguese Republic Journal - Diário da República. That search included key words such as fishing regulation, 
bivalves harvesting and trade, Manila clam, and Ruditapes philippinarum. Specific regulation for the studied areas (Ria de Aveiro, Óbidos lagoon, Tagus and Sado estuaries) were also collated.

(ii) Step 2 - Collation of available information on the current state of the Manila clam exploitation in Portugal including not only published bibliography but also technical reports of projects developed in the studied systems, namely GEPETO (Maia and Gaspar, 2014), PROMAR (Chainho et al., 2016) and NIPOGES (Chainho et al., 2020), and other gray literature. These projects were developed within a framework of interaction between different stakeholders (harvesters, decision makers and researchers), which has provided support for the identification of management measures that were incorporated in the governance scenarios proposed in this study. These interactions included the collaboration between harvesters and researchers during sampling surveys, participatory meetings with all relevant stakeholders in each system and specific meetings between researchers and selected stakeholders;

The harvesting techniques and respective zonation, the abundance and spatial distribution of the Manila clam, the harvesting community characterization, the annual catches, the market value and product chain (harvesting, processing, transport and marketing) were characterized for each studied system. Detailed information for some aspects was only available for the Tagus estuary.

Problems identified in the of Manila clam exploitation in each case study system were summarized and classified according to different importance levels, with "+" corresponding to "low importance," "++" to "high importance" and " +++ " to "very high importance."

(iii) Step 3 - Assessment of the compliance of the activity with the legal framework and spatial planning instruments in force in the case study areas. Spatial planning instruments include protected areas and Nature 2000 areas. These documents are available in the website of the national authority for nature conservation (ICNF). The assessment of compliance was based on the cross comparison between the zonation of current harvesting activities with the zonation of protected areas and conditioning factors in force in these areas, in particular restrictions to fishing and harvesting activities.

(iv) Step 4 - Analysis of management strategies applied to the Manila clam fishery in different EU countries with different management objectives as well as the management strategies proposed for the Tagus estuary (Chainho et al., 2016). The adequacy of management models used in other EU member states for the Portuguese scenarios were evaluated based on: the area of the exploited system, the abundance of Ruditapes philippinarum, the harvesting practices and the characteristics of the fishing community. Management strategies applied and/or proposed in each European case study were summarized and associated to the Portuguese systems for which their application could be more relevant. Different management models were defined for the Portuguese case study systems based on the results of this analysis and taking into account the legal framework and spatial planning instruments in force. The strategies proposed for each system and respective characterization were summarized, with the identification of the major and complementary management measures.

\section{RESULTS}

\section{Assessment of the Portuguese Legal Framework (Step 1) Harvesting Regulation}

The Tagus estuary is the only system in Portugal where the harvesting of $R$. philippinarum is regulated by Ordinance $85 / 2011$, which defines the technical requirements of the clam rake and establishes a maximum daily catch amount of $80 \mathrm{~kg}$ per harvester. The harvesting of $R$. philippinarum in the Tagus estuary is currently encompassed under the general umbrella of Ruditapes spp. in the list of "Marine animal species that may be harvested" published in Ordinance No. $1228 / 2010$. The production and commercialization of live marine bivalve mollusks, echinoderms, tunicates and gastropods are regulated by Ordinance No. 1421/2006. The exploitation of marine bivalve species in Ria de Aveiro and Óbidos lagoon is regulated by Ordinance No. 563/90 and Ordinance No. 567/90, respectively, but the Manila clam is not included as an exploitable species in these documents. This activity is not regulated for the Sado estuary since no bivalve species are included in Ordinance No. 562/90, that regulates fishing activities in Sado estuary. Table 1 summarizes the main legal documents related to this activity.

Recreational harvesting is also regulated by Ordinance No. $14 / 2014$, which indicates the allowed harvesting techniques and establishes a maximum daily catch amount of $5 \mathrm{~kg}$ per harvester (Table 1).

The European Union has established a classification system for bivalve molluscs in coastal lagoon zones according to the levels of microbiological contamination in the bivalves by analyzing the "Escherichia coli/100 g level," presented in EU Regulation (EC) No 854/2004 of the European Parliament and of the Council of 29 April 2004:

- A - $\leq 230-$ Bivalves can be harvested and marketed for direct human consumption;

- $\mathrm{B}->230$ e $\leq 4600$ - Bivalves can be harvested and transport to purification, transposition or transformation in an industrial unit;

- $\mathrm{C}->4600 \mathrm{e} \leq 46000$ - Bivalves can be harvested and transport to long time transposition or transformation in an industrial unit;

- Harvesting forbidden $->46000$ - Bivalves cannot be harvested.

The classification of estuarine and coastal lagoon zones addressed in this manuscript for Manila clam exploitation, regarding the levels of microbiological contamination, according 
TABLE 1 | Summary of the main legal documents regulating Manila clam harvesting in Portugal.

\begin{tabular}{|c|c|}
\hline Document & Subject and Constraints \\
\hline $\begin{array}{l}\text { Ordinance } 1102-\mathrm{B} / 2000 \text {, } \\
\text { November } 22 \text {, changed by } \\
\text { Ordinance No. 1228/2010, } \\
\text { December } 6 \text { - General } \\
\text { Harvesting Regulation. }\end{array}$ & $\begin{array}{l}\text { Establishes the legal framework for the } \\
\text { harvesting of marine animal species in ocean } \\
\text { waters and in maritime and non-maritime inland } \\
\text { waters. }\end{array}$ \\
\hline $\begin{array}{l}\text { Ordinance No. } 85 / 2011 \text {, } \\
\text { February } 25 \text { - Fishing regulation } \\
\text { in non-maritime inland waters } \\
\text { of the Tagus river. }\end{array}$ & $\begin{array}{l}\text { Establishes legal regulations for fishing in the } \\
\text { non-maritime inland waters of the Tagus river. } \\
\text { Maximum daily catch amount per harvester } \\
\text { with clam rake: } 80 \mathrm{~kg} \text {. }\end{array}$ \\
\hline $\begin{array}{l}\text { Ordinance No. } 14 / 2014 \text {, } \\
\text { January } 23 \text { - Regulation of } \\
\text { recreational fishery }\end{array}$ & $\begin{array}{l}\text { Defines the harvesting techniques, } \\
\text { conditionings, licensing terms and fees } \\
\text { applicable to the exercise of recreational fishing } \\
\text { in ocean waters, maritime inland waters or } \\
\text { non-maritime inland waters under the } \\
\text { jurisdiction of the maritime authority. } \\
\text { Maximum daily catch amount per } \\
\text { harvester: } 5 \mathrm{~kg} \text {. }\end{array}$ \\
\hline Urainance No. 27/2001, & Minimum size for the Manila clam landing: $4 \mathrm{~cm}$ \\
\hline
\end{tabular}

January 15 - Regulation of species minimum size

Ordinance No. 1421/2006, December 21 - Regulation for the production and trading of live marine bivalve mollusks, echinoderms, tunicates and gastropods.

Ordinance No. 563/90, July 19 - Fishing regulation in Ria de Aveiro

Ordinance No. 1026/2004, August 9 and Ordinance No. 575/2006, June 19 complete the previous one.

Ordinance No. 567/90, July

19 - Fishing regulation in

Óbidos lagoon

Ordinance No. 483/2007, April

19 completes the previous one.

Ordinance No. 562/90, July

19 - Fishing regulations in Sado river

\begin{abstract}
Establishes the regulation for the production and sale of live marine bivalve mollusks, echinoderms, tunicates and gastropods.
\end{abstract}

Establishes the regulation of fishing in Ria de Aveiro, allowing the use of clam rake. Maximum daily catch amount per harvester (R. decussatus): $2 \mathrm{~kg}$.

Maximum daily catch amount with clam rake (R. decussatus): $7 \mathrm{~kg}$.

Establishes the regulation of fishing in Óbidos lagoon, allowing the use of clam rake.

Establishes the regulation of fishing in the Sado river, not including any bivalve harvesting device.

to Order No. 2102/2019, March 1, were (at the time of this study - 2019):

- Ria de Aveiro - zones B and C;

- Óbidos lagoon - B;

- Tagus estuary - C;

- Sado estuary - zones B and C.

\section{Spatial Planning}

Spatial planning is a fundamental instrument for the conservation of nature and biodiversity, and can be used to help regulators organize land use by taking into account ecologically sensitive areas, both for habitats as well as protected species within national Protected Areas and Nature 2000 Network.

In Portugal, within the current legal framework for National Spatial Planning, Special Spatial Plans (SSP's) were developed which supersede any other territorial spatial plan, protecting natural values. Special Spatial Plans range include Protected Areas, coastal areas and estuaries.
The Spatial Planning Instruments (SPI's) in force in the areas addressed in this study are:

- Coastal Spatial Plans (CSP):

- Ovar - Marinha Grande (Ria de Aveiro) (Resolution of the Ministers Council No. - 142/2000, October 20);

- Alcobaça - Mafra (Óbidos Lagoon) (Resolution of the Ministers Council No. o 11/2002, January 17);

- Sintra - Sado (Tagus and Sado estuaries) (Resolution of the Ministers Council No. 86/2003, June 25);

- Protected Areas Spatial Plans (PASP):

- Tagus estuary Nature Reserve Spatial Plan (TENRSP) (Resolution of the Ministers Council No. 177/2008, November 24);

- Sado estuary Nature Reserve Spatial Plan (SENRSP) (Resolution of the Ministers Council No. 182/2008, November 24);

- Natura 2000 Network Sectoral Plan (N2000NSP) (Resolution of the Ministers Council No. 115-A/2008, July 21).

The CSP's and PASP's are integrated into the SSP's, as signed by Law No. 48/98, August 11, which established the "Bases of spatial planning and urbanism policy." The N2000NSP was approved by Resolution of the Ministers Council No. 115-A/2008.

\section{Coastal Spatial Plans}

Of the estuarine and coastal lagoon systems addressed in this study, only a part of the Óbidos lagoon, in which there is no Manila clam exploration, is referenced in the zoning map of the CSP Alcobaça - Mafra (Resolution of the Ministers Council No. $11 / 2002)$. This is due to the fact that the range of CSP's is from bathymetry of $-30 \mathrm{~m}$ to inland areas up to $500 \mathrm{~m}$ from the coast, which means that none of the other addressed systems are indicated in these documents.

\section{Protected Areas Spatial Plans}

The PASP relevant to this study are the Tagus Estuary Nature Reserve Spatial Plan (TENRSP) (Resolution of the Ministers Council No. 177/2008) and the Sado Estuary Nature Reserve Spatial Plan (SENRSP) (Resolution of the Ministers Council No. 182/2008).

According to these documents, both estuarine areas of the nature reserves were divided and classified according to the following zonation system:

- Total Protection;

- Partial Protection Type I;

- Partial Protection Type II;

- Complementary Protection.

These areas correspond to progressively less restrictive protection levels, with the highest level (Total Protection) attributed to areas with higher value and sensitivity, while the lowest level of protection (Complementary) is attributed to areas with reduced value or sensitivity. Critical areas for species and 
habitats of community importance were largely classified with the highest levels of protection.

\section{Natura 2000 Network Sectoral Plan}

The N2000NSP encompasses Sites of Community Importance (SCI's) and Special Protection Areas (SPA's), establishing guidelines for the management of these areas. Manila clam harvesting is not permitted with gears that re-suspend the sediment in the SPA's - Ria de Aveiro, SCI - Tagus Estuary and SCI - Sado Estuary (Resolution of the Ministers Council No. 115-A/2008, July 21).

\section{Current State of the Manila Clam Exploitation in Portugal (Step 2)}

In the Tagus estuary, the abundance of Manila clams and their accessibility, particularly in the middle estuary, coupled with the fact that it has become an economically appealing activity (Garaulet, 2011), has fundamentally altered the dynamics of this estuarine system's clam fishery. Most licensed harvesters changed their target species to the Manila clam and started using new harvesting techniques (Ramajal et al., 2016). Moreover, there was a significant increase of the number of unlicensed harvesters. Project PROMAR estimated around 1700 harvesters operating in the Tagus estuary in 2014-2015, although less than 200 had been attribute (Chainho et al., 2016). These "new harvesters" included unemployed people, professionals from fields unrelated to seafood, and recreational harvesters, the majority of whom are engaged in illegal, unregulated, and unreported (IUU) fishing activities (Ramajal et al., 2016).

Recent survey flights performed in the scope of the NIPOGES project over the Ria de Aveiro and the Sado and Tagus estuaries have confirmed that the Tagus estuary is still the most important system for the Manila clam harvesting. Preliminary, and yet unpublished, aerial observations indicate that there are approximately 4 to 5 time more manual, rake and snorkel harvesters operating in the Tagus estuary (approximately 600 harvesters observed daily) in comparison to the Sado estuary (approximately 130 harvesters observed daily). It is important to note that these counts do not include techniques which are known to occur in the Tagus but are not possible to identify from the air such as diving and dredging.

The Ria de Aveiro has similar amounts of manual, rake and snorkel harvesters operating in the system as the Sado (approximately 120 harvesters observed daily), however, landing data from DGRM and interviews with these harvesters indicate that the target species are cockles and that clams make up a small amount of the daily catch (Figure 2).

The number of harvesters in the Óbidos lagoon, the smallest case study system, was also assessed by the NIPOGES project, using land-based observation points over a period of 7 months. An average of 37 harvesters/day was counted and these harvesters were using hand collection, rake, and snorkel. No SCUBA diving or clam dredging are known to having ever been used in this system.

The study previously conducted in the Tagus estuary indicated that 90 percent of Manila clam catches are exported to Spain, with reported annual landings ranging from 4,000 to $17,000 \mathrm{t}$, corresponding to a business value of $€ 10$ million to $€ 23$ million (Ramajal et al., 2016). Nevertheless, only an average of $52 \mathrm{t}$ was reported as the Tagus estuary landings between 2014 and 2018, while in the Sado estuary the Manila clam average landing was $573 \mathrm{t}$ for the same period (Figure 2). The absence of specific regulation for other systems where the species occur makes it easy for criminals to mislabel the catches origin. Specimens collected in the Tagus estuary are frequently transported and landed in the area of jurisdiction of Setúbal maritime authority, where they are erroneously indicated as having origin in the Sado estuary (Ramajal et al., 2016; Table 2). This system has areas classified as zone B, and there is no daily catch limit or any other type of limitations. Landings records from 1990 to 2019 show an increase in the amount of bivalves captured in the Sado estuary after 2010 mainly related to $R$. philippinarum landings, corresponding exactly to the period when the Manila clam started to be intensively explored in the Tagus estuary (Figure 2). However, recent scientific results indicate that the quantity of landings recorded as coming from that system is extremely unlikely (Cabral et al., 2020), which leads to the conclusion that the true origin of a large part of the catches is the Tagus estuary. The Tagus estuary was classified as zone C in 2015, requiring the transposition or industrial processing of the Manila clam specimens before being marketed. The current lack of designated transposition zones and the inability to industrially process the catches mean that the consumption of Manila clam captured in the Tagus estuary incurs a risk to public health (Carvalho, 2017). That was shown by the unconformities found during the inspections conducted by the Portuguese Food and Economic Safety Authority, which reported a high number of unsatisfactory results for microbiological analysis conducted in Manila clam specimens collected at restaurants in the areas of Lisbon and Setúbal (Oliveira, 2018).

The vast majority of first transactions of the Manila clam in the Tagus are made to illegal intermediaries (Ramajal et al., 2016) and although this activity involves a large and complex value chain, this parallel market devaluates the resource introduces a market imbalance (Carvalho, 2017).

Observations conducted during the development of the PROMAR and NIPOGES projects and issues raised by different stakeholders during participatory and other specific meetings list several situations that make it difficult to manage the harvesting and trade of $R$. philippinarum in Portugal (Ramajal et al., 2016; Carvalho, 2017; Chainho et al., 2020). These problems have distinct importance levels in the different case study systems, as shown by the classifications attributed in Table 2 .

\section{Assessment of the Compliance of the Activity With the Legal Framework and Spatial Planning (Step 3) Legal Non-conformities Practiced in Harvesting and Trade}

The Manila clam harvesting includes activities incorporate Illegal, Unreported and Unregulated (IUU) fishing activities. Most active harvesters in the Tagus estuary in 2014/2015 were unlicensed 


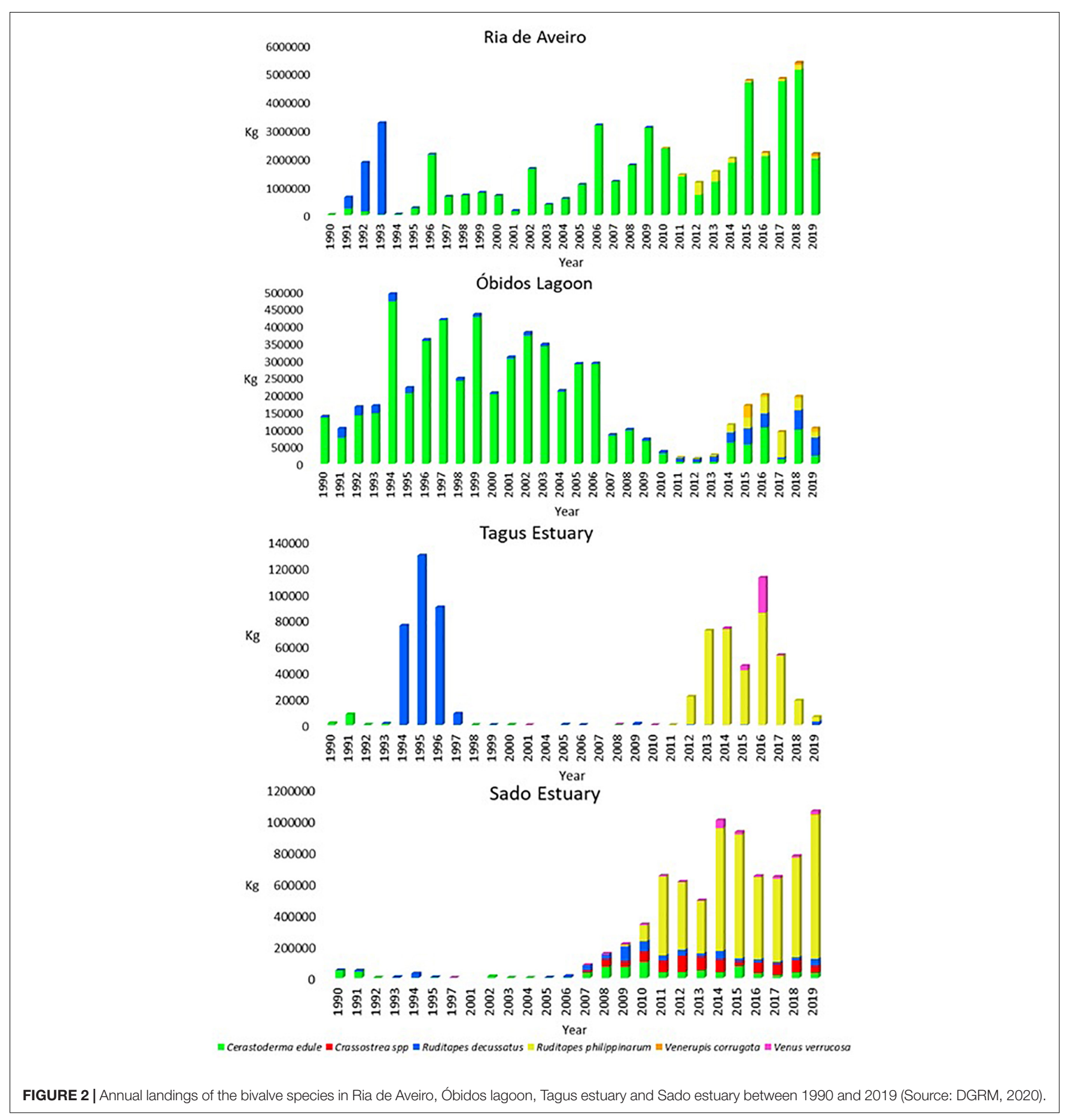

(90\%) and most of the licensed harvesters used illegal fishing gears such as clam dredges and SCUBA diving (Ramajal et al., 2016; Figure 3) (Illegal fishery). Most harvesters in Ria de Aveiro and Óbidos lagoon are licensed for bivalve harvesting, although there is no specific regulation for the Manila clam harvesting in these systems (Tables 1, 2) (Unregulated fishery).

All harvesting devices not included in Ordinance $\mathrm{n}-1102$ B/2000 and Ordinance no 14/2014 used in the Sado estuary are illegal since the general harvesting regulation and recreational bivalve harvesting apply to this activity in the absence of specific regulation. All harvesters observed in Ria de Aveiro and Óbidos lagoon were using tools permitted in those systems.

More than $80 \%$ of the catches of the Tagus estuary were not reported to the competent authority (DOCAPESCA), based on the landing data (Figure 2) and observation-based estimates of the Manila clam landings (Ramajal et al., 2016; Carvalho, 2017) (Unreported fishery). Using clam dredge, a harvester can expect to land around $350 \mathrm{~kg} / \mathrm{day}$ (Carvalho, 2017). 
TABLE 2 | Summary and classification of major problems identified in the harvesting of Manila clam in Ria de Aveiro, Óbidos lagoon, Tagus estuary and Sado estuary.

\begin{tabular}{|c|c|c|c|c|}
\hline Major problems & $\begin{array}{l}\text { Ria de } \\
\text { Aveiro }\end{array}$ & $\begin{array}{l}\text { Óbidos } \\
\text { lagoon }\end{array}$ & $\begin{array}{l}\text { Tagus } \\
\text { estuary }\end{array}$ & $\begin{array}{l}\text { Sado } \\
\text { estuary }\end{array}$ \\
\hline $\begin{array}{l}\text { Fast growth of the activity in a short } \\
\text { time period }\end{array}$ & ++ & ++ & +++ & + \\
\hline $\begin{array}{l}\text { The decentralized participation of many } \\
\text { people }\end{array}$ & + & + & +++ & + \\
\hline $\begin{array}{l}\text { Practice of various illegalities } \\
\text { throughout the process (harvesting, } \\
\text { purification, transport and trade) }\end{array}$ & + & + & +++ & + \\
\hline $\begin{array}{l}\text { Existence of a parallel market, including } \\
\text { outside the country. }\end{array}$ & + & + & +++ & +++ \\
\hline $\begin{array}{l}\text { Lack of association among the various } \\
\text { players in the activity }\end{array}$ & ++ & + & +++ & + \\
\hline Absence of species-specific legislation & +++ & +++ & + & +++ \\
\hline Absence of system-specific legislation & + & + & + & +++ \\
\hline $\begin{array}{l}\text { Authorities unable to manage, regulate, } \\
\text { monitor and supervise the activity due } \\
\text { to limited human and logistical } \\
\text { resources }\end{array}$ & ++ & + & +++ & + \\
\hline
\end{tabular}

These issues are classified according to importance level at each study system as "+" for "low importance," "++" for "high importance" and "+++" for "very high importance."

Since the maximum daily catches regulated for the Tagus estuary are $80 \mathrm{Kg} /$ day/harvester, most catches of this system are unreported or reported as collected in the Sado estuary since maximum daily catches are not regulated in that system (Unregulated fishery).
Direct sales by harvesters in illegal markets, restaurants and coffee houses and not writing receipts of the Manila clam sales are other examples of Unreported fisheries.

The majority of primary and secondary intermediaries are not licensed to sell bivalve mollusks (particularly in the Tagus estuary). The transport of batches with false labels is done without a certificate, not respecting the basic rules of food safety or customs laws (particularly in the Tagus estuary) and, as already indicated, non-compliances with the food safety requirements were verified in restaurants and other commercial entities with direct sale to the consumer (Oliveira, 2018).

\section{Conditions Not Respected by the Exploitation of R. philippinarum}

Ramajal et al. (2016) (Figure 4) mapped the areas under exploitation in the Tagus Natural Reserve, which indicated that Manila clam harvesting occurs in the Areas of Partial Protection Type II and Complementary Protection. - In the subtidal zone there is harvesting using clam rake, SCUBA diving and clam dredge; in the intertidal zone there is manual harvesting.

Harvesting using a telescopic clam rake and snorkeling in the subtidal zone occurs in very specific areas of the estuary that are not incorporated in the Tagus Estuary Nature Reserve. The Manila clam harvesting is less significant in the Sado Estuary Nature Reserve, occurring in specific areas with Partial Protection Type II or Complementary Protection and using techniques allowed for recreational harvesting (unpublished data).

Therefore, Manila clam harvesting collides with the constraints imposed by TENRSP, regarding the gear and equipment used in the activity (SCUBA diving and clam dredge),

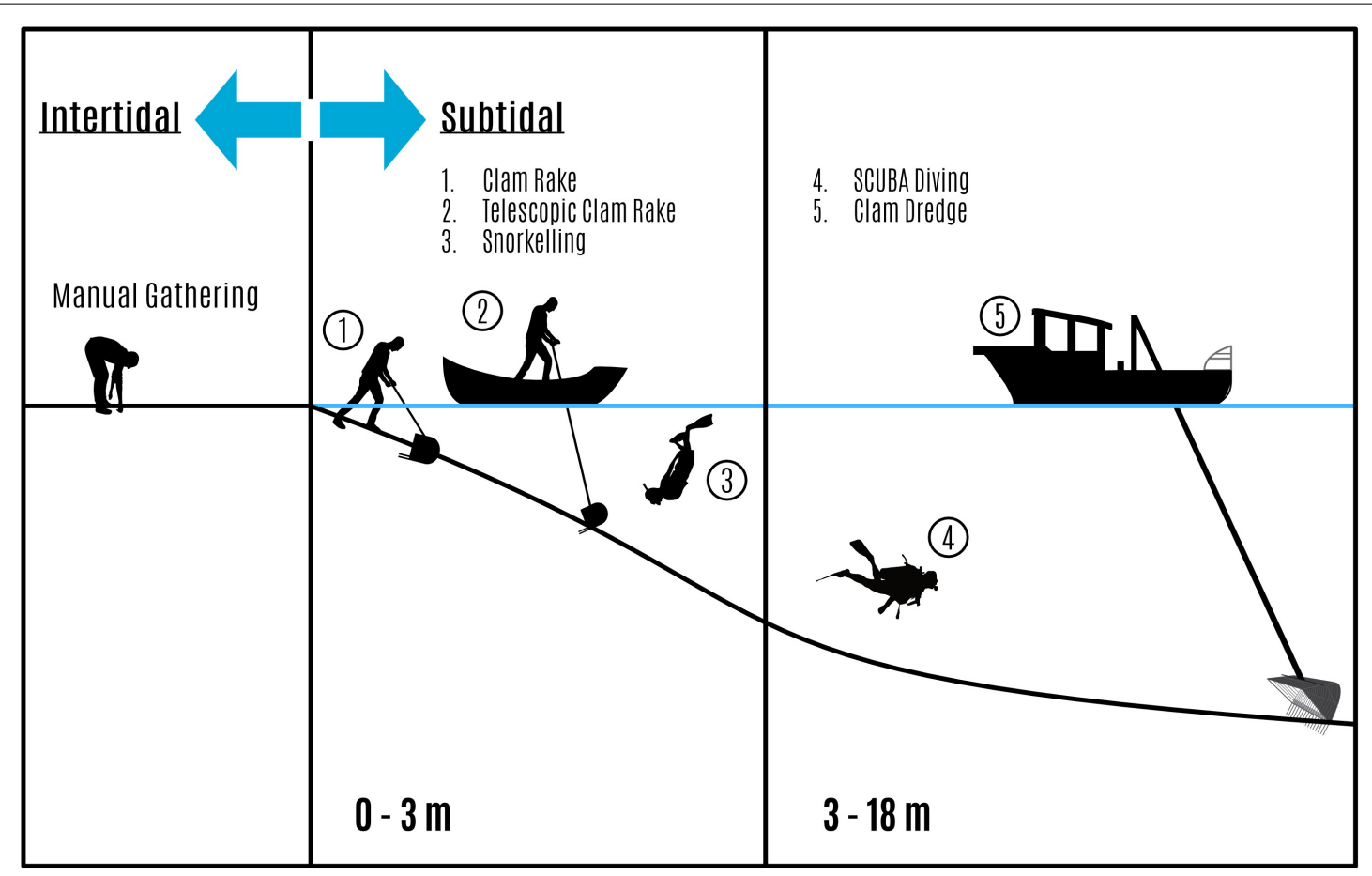

FIGURE 3 | Manila clam harvesting techniques depending on the depth (adapted from Ramajal et al., 2016). 


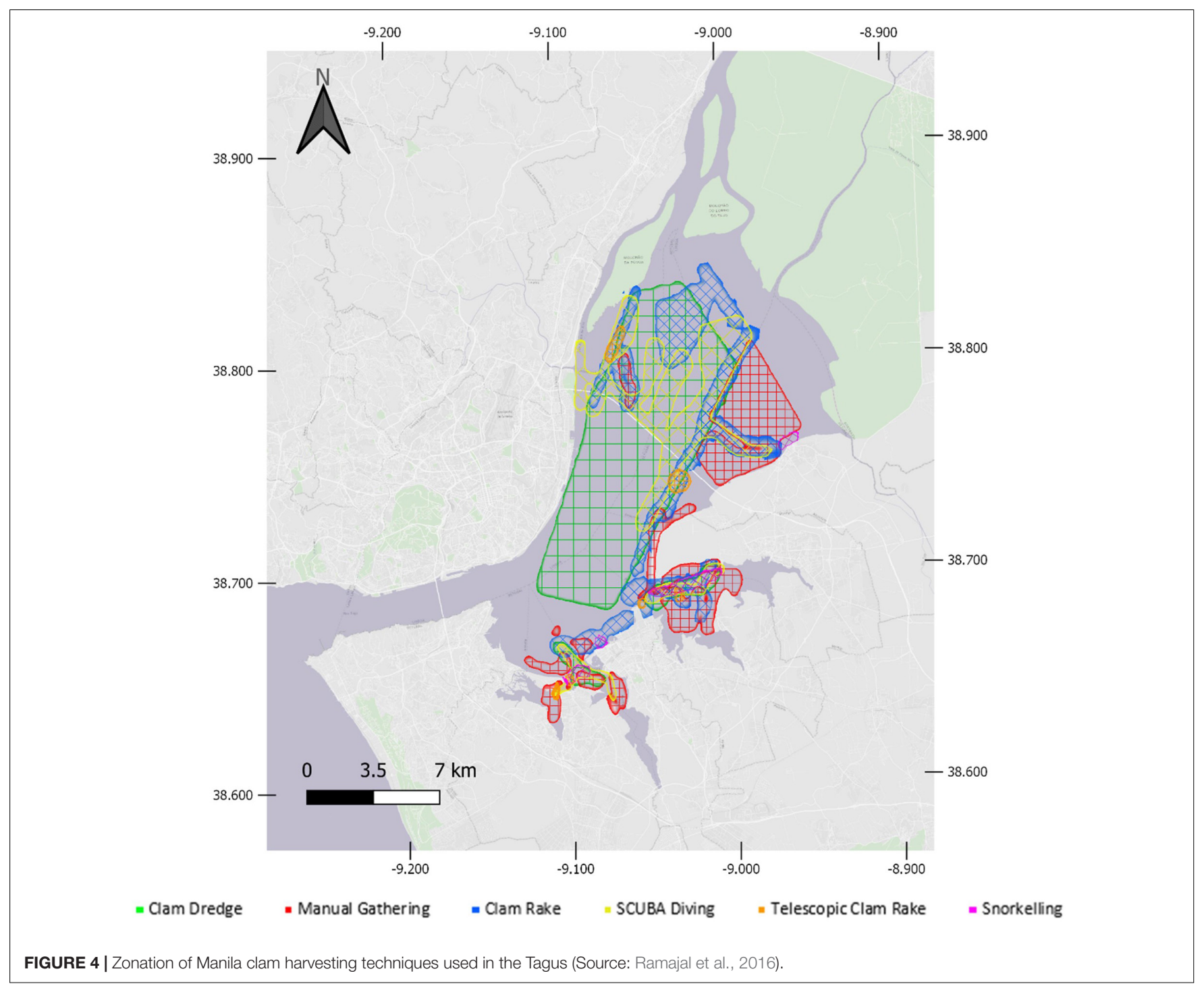

as well as in the practice of these techniques in areas of Partial Protection Type II.

In the other systems addressed in this study, there is no occurrence of infractions of the regulations of Spatial Plans S in force in these systems. However, this is probably due to constraints imposed in these systems not being as restrictive as for the Tagus estuary.

\section{Case Studies in the European Union (Step 4)}

The Manila clam is distributed throughout Europe and the management of this resource has been the subject of study in several countries such as France, Spain and Italy.

In the Arcachon Bay, France, this species colonized most of the system (Bald et al., 2009). A study to evaluate which management measures were the most appropriate for sustainable exploitation of thissystem's resource concluded that the most important measure is to increase the legal minimum catch size, as it allows a considerable increase in population and, consequently in long term, an increase in annual catches and fishers income. Other proposed measures are to reduce the capture season and increase no-take zones (Bald et al., 2009). A co-management Manila clam process between fishermen, scientists and administration has also been in place since 2003 (Caill-Milly et al., 2021). This collaborative process takes the form of various collective actions such as co-organized monitoring surveys, research programs that have been intensified since 2006 and working groups to have discussion and make decisions (Caill-Milly et al., 2021). The questioning mainly concerned the capability of the Manila clam stock renewal, the establishment of closed areas and reseeding (Caill-Milly et al., 2021). This work (Caill-Milly et al., 2021) also highlighted some difficulties such as the available funds to schedule regular surveys (with a financial contribution supported by the professionals which is the structure carrying out the campaign from funders) and available funds for research programs applied to local issues. All the actions implemented in Arcachon to ensure the sustainability of the Manila clam stock 
illustrate that this species is not perceived as invasive (Caill-Milly et al., 2021), which is not the case in other countries where this species occurs such as Portugal (Ramajal et al., 2016; Carvalho, 2017), Spain (Juanes et al., 2012; Bidegain et al., 2013) and Italy (Pellizzato and Da Ros, 2005; Vincenzi et al., 2006, 2011; Brusà et al., 2013).

In Spain, in Plentzia and Mundaka estuaries (Basque Country), the species $R$. decussatus has been exploited by both professional and illegal fishers (Bald and Borja, 2002). Different alternatives for the exploitation of this species in these systems were simulated by Bald and Borja (2002). In this study, three management measures were proposed: to halve the current number of harvesters, limit the capture season to 1 month per year and to establish a sustainable minimum limit for the species' biomass.

The Santander Bay and the Marismas de Santoña (Basque Country) are considerably productive estuaries in terms of $R$. decussatus and $R$. philippinarum permanent stock (Bidegain et al., 2013). The clam fishing management in these estuaries has been based on the establishment of a minimum catch size and no-take areas through annual regional regulations (Bidegain et al., 2013).

In Santander Bay, the estuarine populations of these two species have been largely exploited by illegal and professional fishers (Juanes et al., 2012). Juanes et al. (2012) carried out a study on mollusk harvesting in this system and the following management measures focusing on the conservation of native species were proposed:

- strict control over the legal minimum catch size;

- establish specific no-take zones in areas where population densities and recruitment of native mollusks are high;

- increased control of the spread and density of cultivated bivalves and/or dispersal of cultivation areas to reduce the potential effects of high densities on natural surrounding populations of native clams;

- incorporation of the fishers into a harvesting co-management system.

The fishers' participation in management is not yet considered in this region, contrasting with the policy practiced in the neighboring region of Galicia for the exploitation of the goose barnacle (Pollicipes pollicipes). The Galician government regulations promote a cooperative management system between fishers' organizations ("cofradías") and the fishing authority (Molares and Freire, 2003).

Access to natural areas of this resource is granted only to licensed fishers belonging to "cofradías" which develop an annual exploitation plan. This plan defines all the components and conditions for the practice of the activity and is evaluated by biologists and technicians of the public administration responsible for fisheries management. Some of the "cofradías" have their own inspection system and therefore impose individual catch limits. Thus, they collaborate with the government's fishing inspection service to prevent harvesting by illegal fishers. In addition, they can also market the catches by managing first-sale markets (Molares and Freire, 2003).
Currently, virtually all available natural areas are included in the exploitation plans accepted by the fishing authorities. The performance of community-managed fisheries using the plans is generally positive, proven by the fact that production (both in biomass and in economic value) has shown an increasing trend since the implementation of this cooperative management system (Molares and Freire, 2003).

A different model has been implemented in Italy, where the Manila clam was introduced and spread to coastal lagoons of the northern Adriatic Sea such as the Venice lagoon (Pellizzato, 1990) and Sacca di Goro (Rossi, 1989).

In Sacca di Goro, the species found favorable environmental conditions for growth and reproduction, replacing the native species $R$. decussatus (Paesanti and Pellizzato, 2000). Currently $10 \mathrm{~km}^{2}$ of the $26 \mathrm{~km}^{2}$ of the lagoon are strongly exploited for the production of $R$. philippinarum (Vincenzi et al., 2006).

A management system defined as a "culture-based fishery" has been practiced in this lagoon. This strategy is based on the division of production areas by the regulatory agency into several concessions, each managed by local clam fisher with a strict set of rules on access limitation and exploitation effort (Vincenzi et al., 2006). Concessions are divided into areas of culture, where mollusks are produced, and fishing areas, where mollusks are exploited (Vincenzi et al., 2011).

This model resulted in the rational management of this resource exploitation (Brusà et al., 2013). The concessions granting process could still be improved upon by evaluating the productivity potential of different locations in the lagoon and thus improving the transparency of decision-making and the sustainability of the activity (Vincenzi et al., 2011).

Further north, Venice lagoon has become the largest annual production site of Manila clam in Italy with an income of 85 to 100 million euros (Melaku et al., 2011), which corresponds to $60 \%$ of the country's total production (Zentilin et al., 2007). It also is the estuarine system with the most people (900) engaged in this economic activity, although initially no regulation was defined for the activity (Solidoro et al., 2003).

This lack of policy led to negative outcomes from both an ecological and economic point of view (Pellizzato and Da Ros, 2005; Melaku et al., 2011; Brusà et al., 2013), such as:

- indiscriminate exploitation of the natural areas;

- use of illegal and/or high impact harvesting techniques with consequent harmful effects on sediments and water;

- conflicts between fishers and other activities carried out in the lagoon;

- inadequate management of nursery areas;

- reduction of the resource's price and high social cost, which cannot be internalized;

- health risks due to harvesting in industrial effluents and polluted areas.

The Province of Venice has begun a gradual shift to a concession regime under the control of GRAL ("Gestione Risorse Alieutiche Lagunari") (Vincenzi et al., 2011) with the aim of restoring the social, environmental and economic sustainability of this activity (Brusà et al., 2013). A total of 
3500 ha was licensed, in which mollusks could be cultured and/or harvested (Pellizzato and Da Ros, 2005). Free access exploitation continued to be allowed in specific areas, but only using a clam rake and respecting a daily catch limit per fisher (Pellizzato and Da Ros, 2005).

Some of the government's most recent proposals were: reducing the number of harvesters operating in the lagoon and remodeling and reducing the areas granted to fishers (Vincenzi et al., 2011). These measures had the purpose of Pranovi et al. (2004); Sfriso et al. (2005); Molinaroli et al. (2007); Vincenzi et al. (2011):

- reducing risks associated with public health due to industrial pollutants or municipal waste;

- minimize the environmental impacts of clam dredges, such as sediment loss, increased water turbidity and the movement of nutrients and pollutants;

- protect habitats with conservation interest, such as seagrass prairies;

- maximize production to minimize fishing effort, both in space and time.

Another issue related to Manila clam culture is this activity's dependence on the collection of natural juveniles seed from the environment (Brusà et al., 2013). The availability of seed is one of the major barriers to the industrialization of the clam production sector (Brusà et al., 2013). Consequently, the management of wild seed and the protection of natural nursery areas were considered priority tasks in order to achieve the sustainability for the current strategy in force (Brusà et al., 2013).

In Sacca di Goro, nursery areas were identified, georeferenced and declared as "no-take" areas (Brusà et al., 2013). Their management was shared among all fishers' associations under a regional committee (“Servizio Economia Itálica, Regione Emilia Romagna"), with the support of a scientific institute ("Istituto Delta Ecologia Applicata”) (Brusà et al., 2013). Local fishers directly manage these areas to optimize their capacity and preserve the resource (removal of macroalgae and bioclasts, addition of sediments, prevention of illegal extraction) (Brusà et al., 2013). Field work is regularly carried out to estimate the available stocks and thus allow for the correct timing of seed collection campaigns, which are regulated by strict access controls (Brusà et al., 2013).

Brusà et al. (2013) proposes the classification of the Venice lagoon nursery areas as "no take" zones, with strict controls to prevent illegal harvesting. This measure would contribute to the restoration and protection of juvenile biomass and would favor the development of mollusk populations in neighboring areas.

Most of the case studies presented in this chapter are management measure proposals that are not yet evaluated regarding their success. The exceptions are the models implemented in Galicia and Italy. In Galicia, as mentioned before, all available natural areas are included in the exploitation plans accepted by the fishing authorities and the production has shown an increasing trend since the implementation of this cooperative management system (Molares and Freire, 2003). In Sacca di Goro, the "culture-based fishery" resulted in the reasonable management of the Manila exploitation (Brusà et al., 2013). On the other hand, in Venice lagoon this system solved some of this activity's problems, but it has not yet been reached the sustainable practice due to the greater complexity it presents (Pellizzato and Da Ros, 2005; Vincenzi et al., 2006, 2011; Brusà et al., 2013).

In Portugal, management strategies for the harvesting of the Manila clam have been also proposed within the scope of the project PROMAR (Chainho et al., 2016). The result was a management proposal, based on the distribution, abundance, growth rate and reproductive cycle of the species, framed by the knowledge of the fishing community and the socioeconomic context of the activity. The management proposal consisted of three alternative strategies and complementary recommendations; these are:

Strategy 1 - A system with concession and free access areas:

- Allocation of concession areas, with the number of licenses to be allocated in each defined, dependant on the ecosystem capacity;

- Zoning - two concession areas to be defined in the area with the greatest Manila clam abundance, with the remaining production area allocated as free access zones.

- Harvesting techniques:

- In concession areas - snorkeling or SCUBA diving if allowed, clam rake and telescopic clam rake;

- In free access areas - manual methods only;

- Licensed fishers for the concession area may exercise their activity only within that area, except for harvesters using SCUBA gear. Non-concessionary harvesters can carry out their activity throughout the remaining authorized area.

Strategy 2 - Free access system:

- Continuation of the Manila clam exploitation management in the Tagus estuary in free access system, with the implementation of the complementary management measures and recommendations indicated below.

Strategy 3 - Harvesting techniques zoning system:

- Organization of harvesting areas according to the techniques used, with the implementation of complementary management measures and recommendations indicated below.

These complementary measures should be implemented regardless of the strategy adopted:

- Increase of the number of licenses for Manila clam harvesting in the Tagus estuary;

- Implementation of a "no take" season;

- Amendments to the recreational fishing regulation (Ordinance No. 14/2014) to reduce the daily catch limits per fishers to $2 \mathrm{~kg}$;

- Regulation of Manila clam harvesting in all systems where it occurs;

- Regulated authorization to use SCUBA diving equipment; 
- Prohibition of professional fishing in the vicinity of effluents from Wastewater Treatment Plants.

Other recommended measures:

- Creation of local warehouses for registering the catches in the most frequented zones, simplifying the documentation to be filled in on the spot and carrying out an awareness campaign on the new format and specific regulations;

- Carrying out regular monitoring campaigns that should include the measurement of environmental conditions;

- Conducting awareness campaigns for the bivalve harvesting and marketing sectors, and for consumers, regarding food safety;

- Professionalization of the sector through incentives to foster associations and entrepreneurship.

None of these strategies have been implemented yet, which does not provide evidence on their adequacy for the management of the Manila clam in Portugal.

\section{DISCUSSION}

The introduction and marked growth of Manila clam populations have caused significant ecological, social and economic changes, creating the need to implement new management models, adapted to the new reality. The Manila clam currently occurs in several estuarine and lagoon systems on the Portuguese coast, but there are marked differences in relation to the abundance and distribution of populations established in the different coastal systems. These differences are directly associated with the changes observed at the level of the fishing communities, with the most profound changes observed in dedicated harvesters collecting Manila clams in the Tagus estuary. These changes have occurred in the last decade and have not yet been accompanied by the necessary adaptation of regulations and management tools. The results of the detailed analysis of the current situation of the activity of Manila clam harvesting in Portugal and of the current planning and management instruments are used as a basis to propose management models inspired by those adopted in other European systems where this species has been occurring for a longer time.

\section{Analysis of Management Models and Application to the Portuguese Case Studies}

Several strategies for managing the exploitation of marine bivalve mollusks in coastal systems that have been applied or proposed in France, Spain, Italy and Portugal are summarized in Table 3, with the identification of the Portuguese case studies for which those strategies seem to be more appropriate.

The proposed measures for Arcachon bay, in France by Bald et al. (2009), and for the Plentzia and Mundaka estuaries, in Spain (Bald and Borja, 2002), were limited as a management model, since they aim only to protect the resource. These measures do not present solutions to combat the illegalities practiced in the activity. In the case of Portuguese systems, this type of approach
TABLE 3 | Summary of management measures applied to different case studies, the strategies applied and/or proposed in each one and assigns a classification according to the Portuguese addressed system in which their application could be more relevant, if applied in Portuguese estuarine systems.

\begin{tabular}{|c|c|c|c|}
\hline Case study & Management measures & $\begin{array}{l}\text { Portuguese } \\
\text { system }\end{array}$ & References \\
\hline $\begin{array}{l}\text { Arcachon } \\
\text { Bay (France) }\end{array}$ & $\begin{array}{l}\text { Increase of the legal minimum } \\
\text { capture size; } \\
\text { Reduction of the capture } \\
\text { season; } \\
\text { Increase of the "no take" zones; }\end{array}$ & $\begin{array}{l}\text { Sado estuary } \\
\text { and Ria de } \\
\text { Aveiro }\end{array}$ & Bald et al., 2009 \\
\hline $\begin{array}{l}\text { Arcachon } \\
\text { Bay (France) }\end{array}$ & $\begin{array}{l}\text { Co-management process } \\
\text { between fishermen, scientists } \\
\text { and administration. }\end{array}$ & $\begin{array}{l}\text { Ria de Aveiro } \\
\text { and Óbidos } \\
\text { lagoon }\end{array}$ & $\begin{array}{l}\text { Caill-Milly et al., } \\
2021\end{array}$ \\
\hline $\begin{array}{l}\text { Plentzia and } \\
\text { Mundaka } \\
\text { Estuaries } \\
\text { (Spain) }\end{array}$ & $\begin{array}{l}\text { Halve the current number of } \\
\text { fishers; } \\
\text { Limitation of the current capture } \\
\text { season to } 1 \text { month per year; } \\
\text { Establishment of a sustainable } \\
\text { minimum limit for the biomass } \\
\text { of the species. }\end{array}$ & $\begin{array}{l}\text { Sado estuary } \\
\text { and Ria de } \\
\text { Aveiro }\end{array}$ & $\begin{array}{l}\text { Bald and Borja, } \\
2002\end{array}$ \\
\hline $\begin{array}{l}\text { Santander } \\
\text { Bay and } \\
\text { Marismas de } \\
\text { Santoña } \\
\text { (Spain) }\end{array}$ & $\begin{array}{l}\text { Establishment of a minimum } \\
\text { capture size; } \\
\text { Establishment of "no take" } \\
\text { zones; } \\
\text { Control of the spread and } \\
\text { density of cultivated bivalves } \\
\text { and/or dispersion of cultivation } \\
\text { areas; } \\
\text { Incorporation of the fishers into } \\
\text { a co-management system. }\end{array}$ & $\begin{array}{l}\text { Óbidos } \\
\text { lagoon }\end{array}$ & $\begin{array}{l}\text { Juanes et al., } \\
\text { 2012; Bidegain } \\
\text { et al., } 2013\end{array}$ \\
\hline $\begin{array}{l}\text { Galicia } \\
\text { (Spain) }\end{array}$ & $\begin{array}{l}\text { Establishment of a community } \\
\text { cooperative management } \\
\text { system ("Cofradías"). }\end{array}$ & $\begin{array}{l}\text { Óbidos } \\
\text { lagoon }\end{array}$ & $\begin{array}{l}\text { Molares and } \\
\text { Freire, } 2003\end{array}$ \\
\hline $\begin{array}{l}\text { Sacca di } \\
\text { Goro and } \\
\text { Venice } \\
\text { Lagoon (Italy) }\end{array}$ & $\begin{array}{l}\text { Establishment of a cooperative } \\
\text { concession management } \\
\text { system ("Culture-based } \\
\text { fishing"); } \\
\text { Classification of the nursery } \\
\text { areas as "no take" zones. }\end{array}$ & $\begin{array}{l}\text { Tagus } \\
\text { estuary }\end{array}$ & $\begin{array}{l}\text { Pellizzato and Da } \\
\text { Ros, 2005; } \\
\text { Vincenzi et al., } \\
\text { 2006; Vincenzi } \\
\text { et al., 2011; } \\
\text { Brusà et al., 2013 }\end{array}$ \\
\hline $\begin{array}{l}\text { Tagus } \\
\text { Estuary } \\
\text { (Portugal) }\end{array}$ & $\begin{array}{l}\text { Strategy } 1 \text { - a system with } \\
\text { concessions and free-access } \\
\text { areas }\end{array}$ & $\begin{array}{l}\text { Tagus } \\
\text { estuary }\end{array}$ & $\begin{array}{l}\text { Chainho et al., } \\
2016\end{array}$ \\
\hline
\end{tabular}

could be more suitable for the Sado estuary, considering that Manila clam harvesting is less significant (unpublished data), and for the Ria de Aveiro, where harvesting of this species is less representative than the exploitation of other species (Figure 2; Maia and Gaspar, 2014). In Ria de Aveiro, it is also pertinent to implement species-specific regulations for the harvesting of bivalve mollusks in order to protect the exploited species.

In Santander Bay and Marismas de Santoña in Spain (Juanes et al., 2012; Bidegain et al., 2013), in addition to resource protection measures, there is also a proposal to incorporate the fishers in a co-management system similar to the one practiced in Galicia region. This measure is relevant to the Óbidos lagoon, where most of the harvesters are legal and there is a reasonable level of association, as well as some stability in the number of harvesters over time.

In Galicia, also in Spain (Molares and Freire, 2003), the most efficient model for the management of a fishing resource was 
implemented, as it involves the entire community in the decision making, based on government guidelines. However, this model is only applicable to small fishing communities, such as the case of Óbidos lagoon, and is not, most likely, an effective model when applied to a large and less organized community such as the Tagus Estuary.

The co-management process between fishermen, scientists and administration recently put in place at Arcachon Bay (CaillMilly et al., 2021) presents a solution to establish working groups in these systems with the aim of organizing surveys and research programs to monitor the annual stock of the exploited species and its capability of stock renewal, therefore supporting the decisionmaking process. This highly organized approach requires the availability of stakeholders aiming to collaborate and a very good communication network to coordinate the inputs of the fishing community, the scientists and administrators. A well organized and empowered fishing community is needed to ensure their commitment in the Manila clam population monitoring surveys in collaboration with researchers. In turn, these must be able to focus their research to meet the needs of a sustainable management of the bivalve stocks, such as investigating causes of high mortalities, to better support management decisions. The success of this co-management processes also depends on having a streamlined administration, capable of providing quick decisions and regulatory/management changes, as a response to new information provided by the fishing and researcher communities. Ideally, this model would be the best to ensure the efficient management of the highly abundant Manila clam population at the Tagus estuary. Nevertheless, the complete lack of organization and association within the fishing community is still a strong barrier to implement this type of approach, as well as the slowness of decision makers in making and implementing decisions and regulatory changes. The more advanced level of organization of the fishing communities and the experience of working in partnership with researchers and decision makers in Ria de Aveiro and Óbidos lagoon makes these case studies best suited for a first try of co-management solutions.

The "culture based fishing" strategy applied by the Italian authorities in Sacca di Goro and in the Venice lagoon, (Pellizzato and Da Ros, 2005; Vincenzi et al., 2011, 2006; Brusà et al., 2013), appears, in our opinion, to be the one with greatest probability of success in the Tagus estuary. This case study has several similarities with the case of the Venice lagoon, in relation to the size and difficulties of managing the activity. By giving local entrepreneurs ownership of concessions this could greatly reduce the burden on local authorities to police illegal harvesting activities, therefore allowing resources to be re-allocated to other problematic areas of the supply chain and create incentives for legal business practices as a condition to retain licenses.

The management proposal outlined for the Tagus estuary (Chainho et al., 2016) included three possible different scenarios. but strategy 1 consisting on the attribution of concession and free access areas seemed to be the most adequate for an experimental pilot study in the Tagus estuary. This system would promote a comanagement process between stakeholders, a decrease of illegal harvesting, an increase in licensing and more efficient monitoring of the activity. The other two Chainho et al. (2016) strategies do not present a solution to address illegal harvesting and therefore are more appropriate for the other case study systems, where IUU is much less significant.

\section{Management Model Proposal}

The crossover of information on the management models adopted in other places where this species is exploited (Table 3) with the strategies and measures proposed by Chainho et al. (2016), allowed for the elaboration of proposals for the systems addressed in this case study (Table 4). These proposals were based on previous knowledge on the exploitation of this species in the different locations, considering the abundance and distribution of the species, the harvesting techniques used in each system, the characteristics of the harvesters' communities, the volume of catches and the value chain (harvesting, processing, transport and marketing).

- Tagus Estuary - A concession and free-access areas system with similarities to Strategy 1 proposed by Chainho et al. (2016) and the strategy of "culture based fishing" (concessions with nursery areas) in practice in Italy (Pellizzato and Da Ros, 2005; Vincenzi et al., 2011, 2006; Brusà et al., 2013), is recognized by the authors as the most promising for the management of the Manila clam harvesting in this system. This model is characterized by:

- Definition of concession exploitation areas that would include commercial exploitation and nursery areas, and non-concession areas, where harvesting would be allowed under a free access system to which the Tagus estuary harvesting regulations apply;

- Additional measures:

- Close monitoring of illegal exploitation located in the Tagus Estuary Nature Reserve areas classified as partial protection type I, partial protection type II or total protection;

- Creation of purification facilities, transposition areas and processing industries for specimens captured in systems with a C classification according to $\mathrm{EU}$ Regulation (EC) No 854/2004;

- Creation of "no take" areas, for the development of natural juveniles (nursery zones);

- Creation of ambulatory markets, in which the Manila clam trade would be exclusive, to minimize Unreported Fshery;

- Restricting the bivalve landings only at the area of jurisdiction of the harvester's license.

- Sado Estuary - Regulation measures with the definition of maximum daily quantities, such as those mentioned in the cases of Arcachon Bay, France (Bald et al., 2009) and the Plentzia and Mundaka estuaries in Spain (Bald and Borja, 2002), are sufficient as there is currently no significant presence of Manila clam in this system, which results in a residual practice of the exploitation of this species;

- Óbidos Lagoon - In this system, most fishers are licensed and use harvesting techniques in accordance with current legislation (Duarte, 2018), which means that a 
TABLE 4 | Summary of the management models proposed for the Portuguese estuarine and lagoon systems and respective characterization and additional measures.

\begin{tabular}{|c|c|c|c|c|}
\hline System & Model & Model characterization & Management/ Monitoring measures & Legislation/ Regulation measures \\
\hline $\begin{array}{l}\text { Tagus } \\
\text { estuary }\end{array}$ & $\begin{array}{l}\text { Concession areas } \\
\text { and free-access } \\
\text { areas }\end{array}$ & $\begin{array}{l}\text { Concession areas: } \\
\text { - Commercial exploitation } \\
\text { - Nursery areas } \\
\text { Non-concession areas: } \\
\text { - Free access system }\end{array}$ & $\begin{array}{l}\text { Management: } \\
\text { - Close monitoring of illegal exploitation located } \\
\text { in TENR partial protection type I, type II or total } \\
\text { protection classified areas } \\
\text { - Creation of purification facilities, transposition } \\
\text { areas and processing industries } \\
\text { Monitoring: } \\
\text { - Regular monitoring campaigns } \\
\text { - Awareness campaigns for harvesters and } \\
\text { consumers }\end{array}$ & $\begin{array}{l}\text { Increase the number of harvesting licenses } \\
\text { Creation of "no take" areas } \\
\text { Amendments to the recreational fishing regulation } \\
\text { (Ordinance No. 14/2014) to reduce the daily } \\
\text { catch limits per fishers to } 2 \mathrm{~kg} \text {. } \\
\text { Regulated authorization to use SCUBA diving } \\
\text { equipment. } \\
\text { Prohibition of professional fishing in the vicinity of } \\
\text { effluents from Wastewater Treatment Plants. } \\
\text { Creation of ambulatory markets } \\
\text { Professionalization of the sector }\end{array}$ \\
\hline $\begin{array}{l}\text { Sado } \\
\text { estuary }\end{array}$ & $\begin{array}{l}\text { Regulation } \\
\text { measures }\end{array}$ & $\begin{array}{l}\text { Definition of maximum daily } \\
\text { quantities. }\end{array}$ & $\begin{array}{l}\text { Management: } \\
\text { - Establish working groups between stakeholders } \\
\text { Monitoring: } \\
\text { - Regular monitoring campaigns } \\
\text { - Awareness campaigns for harvesters and } \\
\text { consumers }\end{array}$ & $\begin{array}{l}\text { Update the system-specific regulation to include } \\
\text { this species. } \\
\text { Professionalization of the sector }\end{array}$ \\
\hline $\begin{array}{l}\text { Óbidos } \\
\text { Lagoon }\end{array}$ & $\begin{array}{l}\text { Co-management } \\
\text { model }\end{array}$ & $\begin{array}{l}\text { Active participation of the } \\
\text { harvesters in: } \\
\text { - maximum daily quantities, } \\
\text { - monitoring process }\end{array}$ & $\begin{array}{l}\text { Monitoring: } \\
\text { - Regular monitoring campaigns } \\
\text { - Awareness campaigns for harvesters and } \\
\text { consumers }\end{array}$ & $\begin{array}{l}\text { Update the system-specific regulation to include } \\
\text { this species. }\end{array}$ \\
\hline $\begin{array}{l}\text { Ria de } \\
\text { Aveiro }\end{array}$ & $\begin{array}{l}\text { Regulation } \\
\text { measures }\end{array}$ & $\begin{array}{l}\text { Definition of: } \\
\text { - maximum daily quantities } \\
\text { - monitoring mechanisms }\end{array}$ & $\begin{array}{l}\text { Management: } \\
\text { - Establish working groups between stakeholders } \\
\text { Monitoring } \\
\text { - Regular monitoring campaigns } \\
\text { - Awareness campaigns for harvesters and } \\
\text { consumers }\end{array}$ & $\begin{array}{l}\text { Update the system-specific regulation to include } \\
\text { this species. } \\
\text { Professionalization of the sector. }\end{array}$ \\
\hline
\end{tabular}

co-management model with the active participation of the fishers, such as the one practiced in Galicia, Spain (Molares and Freire, 2003), could be the most advantageous for promoting sustainable exploitation of this species;

- Ria de Aveiro - In this systems bivalve mollusk harvesting targets different species depending on the time of year (Maia and Gaspar, 2014). Therefore, it may justify regulations measure that include maximum daily quantities and mechanisms of monitoring the activity.

The inclusion of this species in the system-specific harvesting regulations is also proposed for the Sado Estuary, Óbidos Lagoon and Ria de Aveiro.

Additional measures should be implemented at a national level since many of the activities of IUU fishing are facilitated by differences in regulation and practices in different coastal systems. The definition of seasonal closures to shellfish harvesting associated to the reproductive cycle is used as a management measure to ensure the replenishment of bivalve stocks. The Manila clam has an extensive spawning period, as was confirmed for the populations in the Ria de Aveiro (Maia et al., 2021) and the Tagus estuary (Moura et al., 2018), starting at the end of spring and extending until autumn. Nevertheless, this type of measure must be comprehensive, in order to protect the various exploitable species that co-occur in the same systems. This might be achieved by setting the closure season during a common breeding season between different species, which in Portugal occurs in June-July. This type of measure would be applicable to all Portuguese coastal systems, as well as any changes of the minimum landing size (MLS), to ensure consistent management across areas. The MLS currently in force in Portugal is $40 \mathrm{~mm}$ (Table 2), similarly to what has been applied to Atlantic waters
(Moura et al., 2017). However the fishing community claims that the Mediterranean waters MLS of $35 \mathrm{~mm}$ should be used in Portugal. A study conducted on the growth of the Tagus estuary population concluded that $R$. philippinarum sexual maturation close to $30 \mathrm{~mm}$ (Moura et al., 2017). These results reinforced by the increase in the abundance of the Manila clam in the Tagus estuary during the last 5 years in spite of intensive exploitation seem corroborate with the fishing communities' expectations.

The implementation of the proposed management models also requires starting to mobilize the relevant stakeholders that have been identified within the development of projects such as PROMAR, GEPETO and NIPOGES. These measures include:

- Constitution of stakeholders working groups at each case study system to start working on the proposed management models, define a collaborative working structure and identify major problems and possible solutions;

- Professionalization of the sector through incentives to foster associations and entrepreneurship amongst harvesters and other relevant stakeholders;

- Carrying out regular monitoring campaigns to assess the Manila clam population status and adjust the regulatory and management measures accordingly;

- Conducting awareness campaigns for the bivalve harvesting and marketing sectors, and for consumers, regarding food safety.

\section{CONCLUSION}

Manila clam harvesting has become an integral part of life for many in Portugal who rely on coastal ecosystems to survive. 
This phenomenon is predominantly felt in the Tagus estuary, due to the large number of people involved and the biomass of Manila clam in the system. The expansion of this activity led to practices that do not respect current legislation, both in relation to harvesting and marketing, as well as constraints arising from spatial planning instruments in force in this system. This situation, coupled with the lack of specific legislation for other systems where this species occurs and is exploited, such as the Ria de Aveiro, the Óbidos lagoon and the Sado estuary, have made the need to develop a management model for the exploitation of this species a relevant topic to explore.

The analysis carried out in this study has demonstrated that the most promising management model for the Tagus estuary, where the exploitation of this resource is particularly strained, is the combination of "culture based fishing" strategy, such as the one in practice in Italy, with a system with concession areas and free access areas, as well as the implementation of several complementary measures aimed at nurturing the creation of infrastructures and legal framework changes. As for the other systems where the exploitation of Manila clam is less intense: creation of specific regulations directed to these systems and implementation of a comanagement model with the active participation of all stakeholders, mainly in the Óbidos lagoon, science-based regulation of a closed season, maximum daily quantities, monitoring of the exploited species annual stocks and improved surveillance of the activity, are the management proposals recommended.

This activity deregulation is untenable due to the illegalities and criminality involved resulting in public health risks. Thus, a sustainable management has to incorporate: (i) legislation and regulations entities; (ii) a stock exploitation organizational model; (iii) effective communication between stakeholders, researchers and public administration; (iv) safeguard of public health; and (v) monitoring plans integrated with the scientific community.

This study addressed different scenarios for the exploitation of an invasive marine bivalve species in different types of Portuguese coastal systems. By comparing these cases with similar ones

\section{REFERENCES}

Bald, J., and Borja, A. (2002). "Modelling the management of clam (Ruditapes decussatus) exploitation in the Plentzia estuary (Basque Country, Northern Spain)," in Proceedings of the 20th International. Conference. System. Dynamic. Soc (Northern Spain), 1-26.

Bald, J., Sinquin, A., Borja, A., Caill-Milly, N., Duclercq, B., Dang, C., et al. (2009). A system dynamics model for the management of the Manila clam, Ruditapes philippinarum (Adams and Reeve, 1850) in the Bay of Arcachon (France). Ecol. Modell. 220, 2828-2837. doi: 10.1016/j.ecolmodel.2009. 03.031

Bidegain, G., and Juanes, J. A. (2013). Does expansion of the introduced Manila clam Ruditapes philippinarum cause competitive displacement of the European native clam Ruditapes decussatus? J. Exp. Mar. Bio. Ecol. 445, 44-52. doi: 10.1016/j.jembe.2013.04.005

Bidegain, G., Sestelo, M., Roca-Pardiñas, J., and Juanes, J. A. (2013). Estimating a new suitable catch size for two clam species: implications for shellfishery management. Ocean Coast. Manag. 71, 52-63. doi: 10.1016/j.ocecoaman.2012. 09.009

Bodoy, A., Maitre-Allain, T., and Riva, A. (1981). Croissance comparée de la palourde européene (Ruditapes decussatus) et de la palourde japonaise across Europe, management models and measures specific for each one were proposed. It's an important step toward the sustainable exploitation of this invasive species and furthermore, establishes a foundation for future management approaches and studies about the exploitation of marine bivalve species in estuarine coastal ecosystems.

\section{DATA AVAILABILITY STATEMENT}

The original contributions presented in the study are included in the article/supplementary material, further inquiries can be directed to the corresponding author.

\section{AUTHOR CONTRIBUTIONS}

PCo is the leading writer and participated in data collection and field work. FC, TG, and PCh participated in the data collection and field work. PCh and JG are co-writers and scientific supervisors. All authors revised the manuscript.

\section{FUNDING}

This publication was financed by Portuguese national funds through FCT - Fundação IP under project reference UIDB/04292/2020 and by the European Union's Horizon 2020 Research and Innovation Programme under grant agreement N810139: Project Portugal Twinning for Innovation and Excellence in Marine Science and Earth Observation PORTWIMS. This study had the funding support from the following projects: NIPOGES (MAR-01.03.02-FEAMP-0013); AQUASADO (MAR-02.01.01-FEAMP-0051); COCKLES (652 EAPA_458/2016); and COASTNET (PINFRA/22128/2016). FCT, IP also provided support via a researcher contract to $\mathrm{PC}$ in the scope of the Scientific Employment Stimulus Programme (2020.01797.CEECIND). TG and FC have been funded by the Ph.D. grants 2020.05001.BD and 2020.06325.BD, respectively.

(Ruditapes philippinarum) dans un écosystème artificiel méditerranéen. Vie Mar. 2, 39-51.

Brusà, R. B., Cacciatore, F., Ponis, E., Molin, E., and Delaney, E. (2013). Clam culture in the Venice lagoon: stock assessment of Manila clam (Venerupis philippinarum) populations at a nursery site and management proposals to increase clam farming sustainability. Aquat. Living Resour. 26, 1-10. doi: 10. 1051/alr/2013042

Cabral, S., Carvalho, F., Gaspar, M., Ramajal, J., Sá, E., Santos, C., et al. (2020). Non-indigenous species in soft-sediments: are some estuaries more invaded than others? Ecol. Indic. 110, 105640. doi: 10.1016/j.ecolind.2019.105640

Caill-Milly, N., Sanchez, F., Lissardy, M., de Montaudouin, X., Bru, N., Kermorvant, C., et al. (2021). Drawing lessons from a pluridisciplinary approach associating stakeholders for a better management of a bivalve population (French Atlantic coast)? Estuarine Coast. Shelf Sci. 251:107194. doi: 10.1016/j.ecss.2021.107194

Carvalho, F. B. (2017). Estado Atual da População de Amêijoa-Japonesa (Ruditapes Philippinarum) do Estuário do Tejo e Impactes da sua Introdução. Lisboa, Port: Faculdade de Ciências da Universidade, 71.

Chainho, P. (2014). Report of the Working Group on Introduction and Transfers of Marine Organisms (WGITMO). ICES CM 2014/ACOM 32. Copenhagen: ICES, 259. 
Chainho, P., Adão, H., Carvalho, F., Castro, A. T., Costa, J. L., Machado, M., et al. (2016). Relatório do Projeto "Amêijoa-Japonesa - Estado Atual da População do Estuário do Tejo, Impactos E Gestão da Apanha”. Diagnóstico e Recomendações. Évora: MARE-ULisboa, DGRM, IPMA, CRIA, Universidade, 13.

Chainho, P. J. L., Costa, A. C., Brito, A., Amorim, R., Melo, J., Guerreiro, C., et al. (2020). Estado Atual das Populações de Amêijoa-Japonesa da Ria de Aveiro, Lagoa de Óbidos E Estuários do Tejo E Sado - Bases Científicas Para Uma Gestão Sustentável do Recurso (MAR-01.03.02-FEAMP-0013). Progress Reporto $f$ the Project NIPOGES. 32. Available online at: https://www.researchgate.net/ publication $/ 353220640$

Chiesa, S., Chainho, P., and Ruano, F. (2016). Country report from portugal. relatório de pesquisa da organização de pesquisa e educação da pesca. Bull. Japan Fish. Res. Educ. Agency 42, 121-123.

Chiesa, S., Lucentini, L., Freitas, R., Nonnis Marzano, F., Figueira, E., Minello, F., et al. (2014). Genetic variability of manila clam Venerupis philippinarum and its hybridization with native clam Venerupis decussata. Biol. Mar. Med. 21, $81-84$.

Duarte, I. M. P. (2018). Comparação da Biologia Reprodutiva da Amêijoaboa, Ruditapes Decussatus, e da Amêijoa Japónica, Ruditapes Philippinarum, da Lagoa de Óbidos, Leiria, Portugal. Dissertação de Mestrado. Escola Superior de Turismo e Tecnologia do Mar, Instituto Politécnico de Leiria, Portugal. 72. Available online at: https://iconline.ipleiria.pt/handle/10400. $8 / 3268$

Food and Agriculture Organization (2020). FAO Fisheries \& Aquaculture-Cultured Aquatic Species Information Programme - Ruditapes Philippinarum (Adams \& Reeve, 1850) [WWW Document]. Available on;ine at: http://www.fao.org/ fishery/culturedspecies/Ruditapes_philippinarum/en (accessed 10.June.2020)

Garaulet, L. L. (2011). Estabelecimento do bivalve exótico Ruditapes philippinarum (Adams er Reeve, 1850) no estuário do Tejo: caracterização da população actual e análise comparativa com a congénere nativa Ruditapes decussatus (Linnaeus, 1758) e macrofauna bentónica acompanhante. 100. Mestrado. thesis, Fac. Ciências, Univ. Lisboa, Port.

Gaspar, M. B. (2010). Distribuição, Abundância e Estrutura Demográfica da Amêijoa-Japonesa (Ruditapes Philippinarum) no Rio Tejo. Relatório Técnico do IPIMAR. 6. Available online at: https://www.researchgate.net/publication/ 285740837

Gorman, D., Mayfield, S., Ward, T. M., and Burch, P. (2011). Optimising harvest strategies in a multi-species bivalve fishery. Fish. Manag. Ecol. 18, 270-281. doi: 10.1111/j.1365-2400.2010.00781.x

Hurtado, N. S., García, C. P., Morán, P., and Pasantes, J. J. (2011). Genetic and cytological evidence of hybridization between native Ruditapes decussatus and introduced Ruditapes philippinarum (Mollusca, Bivalvia, Veneridae) in NW Spain. Aquaculture 311, 123-128. doi: 10.1016/j.aquaculture.2010. 12.015

Juanes, J. A., Bidegain, G., Echavarri-Erasun, B., Puente, A., García, A., García, A., et al. (2012). Differential distribution pattern of native Ruditapes decussatus and introduced Ruditapes phillippinarum clam populations in the Bay of Santander (Gulf of Biscay): Considerations for fisheries management. Ocean Coast. Manag. 69, 316-326. doi: 10.1016/j.ocecoaman.2012. 08.007

Kuzdas, C., and Wiek, A. (2014). Governance scenarios for addressing water conflicts and climate change impacts. Environ. Sci. Policy 42, 181-196. doi: 10.1016/j.envsci.2014.06.007

Maia, F., Barroso, C., and Gaspar, M. (2021). Ciclo Reprodutivo, Índice de Condição e Tamanho de Primeira Maturação Sexual da Amêijoa-Japonesa Ruditapes Philippinarum (Adams \& Reeve, 1850) na Ria de Aveiro, Portugal. Relatórios Científicos e Técnicos do IPMA- Série Digital. 32. Available online at: https://www.researchgate.net/publication/352743009

Maia, F., and Gaspar, M. (2014). Case Study: Clam Harvesting in the Ria de Aveiro. Biology and Management of Bivalve Harvesting in Ria de Aveiro. Gepeto Project Techncical Report. Lisbon: The Portuguese Institute for Sea and Atmosphere (IPMA).

Melaku, D., Campostrini, P., Riva, S. D., Pizzo, L., Rossetto, L., and Solidoro, C. (2011). Addressing sustainability of clam farming in the venice lagoon. Ecol. Soc. 16, 29.

Melià, P., De Leo, G. A., and Gatto, M. (2004). Density and temperaturedependence of vital rates in the Manila clam Tapes philippinarum: a stochastic demographic model. Mar. Ecol. Prog. Ser. 272, 153-164. doi: 10.3354/ meps 272153

Melià, P., and Gatto, M. (2005). A stochastic bioeconomic model for the management of clam farming. Ecol. Modell. 184, 163-174. doi: 10.1016/j. ecolmodel.2004.11.011

Molares, J., and Freire, J. (2003). Development and perspectives for communitybased management of the goose barnacle (Pollicipes pollicipes) fisheries in Galicia (NW Spain). Fish. Res. 65, 485-492. doi: 10.1016/j.fishres.2003.09.034

Molinaroli, E., Guerzoni, S., Sarretta, A., Cucco, A., and Umgiesser, G. (2007). Links between hydrology and sedimentology in the Lagoon of Venice. Italy. J. Mar. Syst. 68, 303-317. doi: 10.1016/j.jmarsys.2006.12.003

Moura, P., Garaulet, L., Vasconcelos, P., Chainho, P., Costa, J. L., and Gaspar, M. B. (2017). Age and growth of a highly successful invasive species: the Manila clam (Ruditapes philippinarum) in the Tagus estuary (Portugal). Aquatic Invasions 12, 133-146. doi: 10.1017/S0025315417001382

Moura, P., Vasconcelos, P., Pereira, F., Chainho, P., Costa, J. L., and Gaspar, M. B. (2018). Reproductive cycle of the Manila clam (Ruditapes philippinarum): an intemsively harvested invasive species in the Tagus Estuary (Portugal). J. Mar. Biol. Assoc. U. K. 98, 1645-1657.

Oliveira, V. (2018). Segurança saNitária dos Moluscos Bivalves Vivos Produzidos em Zonas Estuarinas Portuguesas e Respetivo Controlo Ofcial. 82. Mestrado. Thesis, Fac. Medicina Veterinária, Univ, Lisboa.

Paesanti, F., and Pellizzato, M. (2000). Tapes Philippinarum. 2nd Edn. Veneto Agric 73.

Pastres, R., Solidoro, C., Cossarini, G., Melaku Canu, D., and Dejak, C. (2001). Managing the rearing of Tapes philippinarum in the lagoon of Venice: a decision support system. Ecol. Modell. 138, 231-245. doi: 10.1016/S03043800(00)00404-X

Pellizzato, M. (1990). “. Acclimatisation of the Tapes philippinarum species and the first experimental rearing basins in Italy," in Tapes Philippinarum, ed. E.S.A.V (Venezia: Biologia e Sperimentazione), 157-170.

Pellizzato, M., and Da Ros, L. (2005). Clam farming quality as a management tool: a proposal based on recent studies in Northern Adriatic lagoons. Aquac. Int. 13, 57-66. doi: 10.1007/s10499-004-9030-6

Pranovi, F., Da Ponte, F., Raicevich, S., and Giovanardi, O. (2004). A multidisciplinary study of the immediate effects of mechanical clam harvesting in the Venice Lagoon. ICES J. Mar. Sci. 61, 43-52. doi: 10.1016/j.icesjms.2003. 10.003

Ramajal, J., Picard, D., Costa, J. L., Carvalho, F. B., Gaspar, M. B., and Chainho, P. (2016). "Amêijoa-japonesa, uma nova realidade no estuário do Rio Tejo: Pesca e pressão social e impacto socio-económico," in Entre Rios e Mares um Património Ambient. Histórias e Saberes. Tomo V da Rede BrasPor, eds L. C. Fonseca, A. C. Garcia, S. D. Pereira, and M. A. C. Rodrigues (Rio de Janeiro: UERJ), 17-30.

Rossi, R. (1989). Pesca e allevamento di vongola verace nella Sacca di Goro. Mare Nostrum 3, 16-18.

Ruano, F., and Sobral, D. V. (2000). "Marine non-indigenous species-current situation in Portugal," in Proceedings of the 1st Symposium on Nonindigenous Species: Introduction, Causes and Consequences (Lisboa: Liga para a Protecção da Natureza), 58-63.

Sfriso, A., Facca, C., and Marcomini, A. (2005). Sedimentation rates and erosion processes in the lagoon of Venice. Environ. Int. 31, 983-992. doi: 10.1016/j. envint.2005.05.008

Solidoro, C., Melaku Canu, D., and Rossi, R. (2003). Ecological and economic considerations on fishing and rearing of Tapes phillipinarum in the lagoon of Venice. Ecol. Modell. 170, 303-318. doi: 10.1016/S0304-3800(03) 00235-7

Velez, C., Galvão, P., Longo, R., Malm, O., Soares, A. M. V. M., Figueira, E., et al. (2015). Ruditapes philippinarum and Ruditapes decussatus under $\mathrm{Hg}$ environmental contamination. Environ. Sci. Pollut. Res. 22, 11890-11904. doi: 10.1007/s11356-015-4397-7

Vincenzi, S., Caramori, G., Rossi, R., and Leo, G. A. D. (2006). A GISbased habitat suitability model for commercial yield estimation of Tapes philippinarum in a Mediterranean coastal lagoon (Sacca di Goro, Italy). Ecol. Modell. 193, 90-104. doi: 10.1016/j.ecolmodel.2005. 07.039 
Vincenzi, S., Zucchetta, M., Franzoi, P., Pellizzato, M., Pranovi, F., De Leo, G. A., et al. (2011). Application of a Random Forest algorithm to predict spatial distribution of the potential yield of Ruditapes philippinarum in the Venice lagoon, Italy. Ecol. Modell. 222, 1471-1478. doi: 10.1016/j.ecolmodel.2011. 02.007

Zentilin, A., Orel, G., and Zamboni, R. (2007). L'introduzione in Europa di Tapes philippinarum (Adams \& Reeve, 1852), la vongola verace filippina. Ann. Ser. Hist. Nat. 17:227.

Conflict of Interest: The authors declare that the research was conducted in the absence of any commercial or financial relationships that could be construed as a potential conflict of interest.
Publisher's Note: All claims expressed in this article are solely those of the authors and do not necessarily represent those of their affiliated organizations, or those of the publisher, the editors and the reviewers. Any product that may be evaluated in this article, or claim that may be made by its manufacturer, is not guaranteed or endorsed by the publisher.

Copyright (๑) 2021 Coelho, Carvalho, Goulding, Chainho and Guerreiro. This is an open-access article distributed under the terms of the Creative Commons Attribution License (CC BY). The use, distribution or reproduction in other forums is permitted, provided the original author(s) and the copyright owner(s) are credited and that the original publication in this journal is cited, in accordance with accepted academic practice. No use, distribution or reproduction is permitted which does not comply with these terms. 